\title{
Perancangan Sistem Pendeteksi Berita Hoax Menggunakan Algoritma Levenshtein Distance Berbasis Php
}

\author{
Nurhayati, Aprilianda Pasaribu \\ Teknik Informatika, STMIK Kaputama
}

\begin{tabular}{l}
\hline \hline Article Info \\
\hline Article history: \\
Received Jun $12^{\text {th }}, 2020$ \\
Revised Aug $8^{\text {th }}, 2020$ \\
Accepted Aug $12^{\text {th }}, 2020$ \\
\\
Keyword \\
Hoax, Levenshtein Distance, \\
TF-IDF, Prepocessing Text, \\
Detection System
\end{tabular}

Article Info

Received Jun $12^{\text {th }}, 2020$

Revised Aug $8^{\text {th }}, 2020$

Accepted Aug 12 $2^{\text {th }}, 2020$

\section{Keyword}

Detection System

\begin{abstract}
Di era 4.0 dimana Internet menjadi bagian penting dalam kehidupan saat ini, informasi dapat dengan mudah di akses kapanpun dan dimanapun. Namun tidak seluruh informasi yang disebarkan melalui internet berupa fakta. Data yang dipaparkan oleh Kementrian Komunikasi dan Informatika berdsarkan survey yang dilakukan pada tahaun 2018 menyebut sebanyak 800.000 situs di Indonesia terindikasi penyebar berita non-fakta atau hoax. Akibat yang ditimbulkan berita hoax sangat berbahaya karena menyerang pikiran alam bawah sadar manusia, sehingga sangat dibutuhkan sistem yang dapat mendeteksi berita hoax. Dalam penelitian ini digunakan database yang berisi dokumen berita hoax. Algoritma yang diterapkan adalah algoritma TF-IDF untuk mengukur bobot suatu kata dalam dokumen hoax dan dikombinasikan dengan algoritma Levenshtein Distance (LD) untuk mengukur jarak antar kata dalam dokumen. Penerapan Metode Levenshtein Distance dalam Sistem Deteksi Hoaxmemiliki beberapa tahap yang dimulai dengan tahap prapemrosesan kata (prepocessing text) dilanjutkan dengan tahap perhitungan TF-IDF dankemudian tahap perhitungan jarak minimum antar kata menggunakan algoritmaLevenshtein Distance. Hasil batas 0,1 pada 40 dokumen yang sudah terklasifikasi sebagai data uji memiliki nilai Precision, Recall dan Accuracy yang tinggi, yaitu Precision1; Recall0,71;dan Accuracy $80 \%$.
\end{abstract}

Copyright $\odot 2020$ STMIK Triguna Dharma. All rights reserved.

\author{
First Author \\ Nama : Nurhayati \\ Program Studi : Teknik Informatika \\ STMIK Kaputama \\ Email: nurhayati_azura@yahoo.co,id
}

\section{PENDAHULUAN}

Di era industri 4.0, internet menjadi bagian penting dalam kehidupan manusia. Internet kini terhubung ke segala segi kehidupan manusia atau dikenal dengan istilah internet of things sehinggahal ini memudahkan manusia untuk mengakses kebutuhan mereka kapan pun dan dimanapun tanpa mengenal batas jarak dan waktu. Kini untuk mengetahui berita terbaru cukup dengan mengakses internet. Segala informasi menyebar dengan mudah dan cepat dan juga dengan begitu mudahnya menjadi viral, walaupun keaslian berita itu belum dapat dipertanggungjawabkan alias hoax. Beberapa informasi hoax disebabkan oleh perseorangan dan beberapadisebabkan oleh organisasi yang mengkhususkan dirinya dalam bidang pembuatanberita dan informasi hoax kemudian menyebarkannya pada masyarakat luas.Pemerintah Indonesia telahmengatur sanksi bagi pelaku berita hoax dalamPasal 28 ayat 1 Undang-Undang No. 11 Tahun 2008 tentangInformasi danTransaksi Elektronik atau Undang-Undang ITE. Dalam pasaltersebut dituliskan bahwa "Setiap orang yang dengan sengaja dan atau tanpa hakmenyebarkan berita bohong dan menyesatkan, ancamannya bisa terkena pidanamaksimal enam tahun dan denda maksimal Rp 1 miliar". Namun hal ini tidak juga menghentikan aksi pelaku berita hoax. Seperti yang telah dilansir oleh situs web CNN Indonesia bahwa data yangdipaparkan oleh Kementerian Komunikasi dan Informatika menyebut adasebanyak 800 ribu situs di Indonesia yang terindikasi sebagai penyebar beritapalsu dan ujaran kebencian (hate speech). Istilah Hoax biasanya disebut sebagai“"virus 


\section{TEORITIS}

\subsection{Hoax}

hoaks merupakan berita palsu yang mengandung informasi yang sengaja menyesatkan orang dan memiliki agenda politik tertentu. Hoaks adalah berita yang misleading alias menyesatkan, informasi dalam berita hoaks juga tidak memiliki landasan faktual, namun disajikan seolah-oleh sebagai serangkaian fakta[2,5]. Setiap tahunnya perkembangan berita hoaks meningkat fantastis. Seperti dilansir dari situs website Kementerian.

\subsection{Algoritma}

Merupakan kumpulan perintah yang saling berkaiatan untuk menyelesaikan suatu masalah. Perintah-perintah ini dapat diterjemahkan secara bertahap dari awal hingga akhir[3]. Dalam penyusunannya diperlukan urutan serta logika agar algoritma yang dihasilkan sesuai dengan yang diharapkan. Algoritma merupakan bagian yang terpenting dan tidak dapat dipisahkan dari pemograman. Oleh karena itu, sebelum membuat suatu program aplikasi, hal pertama yang harus kita pahami adalah algoritma atau prosedur pemecahannya. Hal ini bertujuan agar program yang telah dibuat dapat sesuai dengan yang diharapkan. Algoritma merupakan hasil pemikiran konseptual. Agar dapat dimengerti oleh komputer, algoritma harus ditranslasikan ke dalam notasi bahasa pemograman.

\subsection{Natural Language Processing}

Natural Language Processing (NLP) atau Pemrosesan Bahasa Alami adalah sebuah otomatisasi proses untuk mengkaji interaksi antara komputer dan bahasa alami manusia yang digunakan dalam kehidupan sehari-hari, karena bahasa alami manusia beraneka ragam sehingga dalam penerapan Natural Language Processing sering menemui permasalahan dalam ambiguitas kata ataupun kata dengan makna ganda. NLP merupakan cabang ilmu kecerdasan buatan yang dikhususkan untuk mengolah pemrosesan linguistik. Bahasa alami manusia memiliki kebergaman dan aturan tata bahasa yang berbeda-beda, sehingga komputer perlu untuk memproses bahasa yang biasa digunakan sehari-hari oleh manusia sehingga dapat memahami maksud dari manusia pengguna sistem. Dalam penerapannya, untuk membuat sebuah sistem yang dapat melakukan Pemrosesan Bahasa Alami terlebih dahulu melalui Text Preprocessing atau tahap sebelum memproses teks.

\subsubsection{Pembobotan Kata (Term Weighting TF-IDF)}

Hal yang perlu diperhatikan dalam pencarian informasi dari koleksi dokumen yang heterogen adalah pembobotan term[4]. Term dapat berupa kata, frase atau unit hasil indexing lainnya dalam suatu dokumen yang dapat digunakan untuk mengetahui konteks dari dokumen tersebut, maka untuk setiap kata tersebut diberikan indikator, yaitu term weight[6]. Rumus umum untuk Term Weighting TF-IDF adalah penggabungan dari formula perhitungan raw TF dengan formula IDF dengan cara mengalikan nilai TF dengan nilai IDF:

$$
\text { tfidf }_{t, d}=\mathrm{tf}_{\mathrm{t}, \mathrm{d}} . \mathrm{idf}_{\mathrm{t}}
$$

Keterangan :

$\begin{array}{ll}\mathrm{tfidf}_{\mathrm{t}, \mathrm{d}} & =\text { bobot term } \\ \mathrm{tf}_{\mathrm{t}, \mathrm{d}} & =\text { term frequency kata t pada dokumen } \mathrm{d} \\ \mathrm{idf}_{\mathrm{t}} & =\text { inverse document frequency kata } \mathrm{t}\end{array}$

Berapapun besarnya nilai $\mathrm{tf}_{\mathrm{t}, \mathrm{d}}$, apabila $\mathbf{D}=\mathbf{d f t}$, maka akan didapatkan hasil 0 (nol), dikarenakan hasil dari log 1, untuk perhitungan IDF. Untuk itu dapat ditambahkan nilai 1 pada sisi IDF, sehingga perhitungan bobotnya menjadi sebagai berikut:

$$
\text { tfidf }_{\mathrm{t}, \mathrm{d}}=\mathrm{tf}_{\mathrm{t}, \mathrm{d}} . \mathrm{idf}_{\mathrm{t}}+1 \text {. }
$$

\subsubsection{Inverse Document Frequency (IDF)}

IDF (Inverse Document Frequency) merupakan sebuah perhitungan dari bagaimana term didistribusikan secara luas pada koleksi dokumen yang bersangkutan. IDF menunjukkan hubungan ketersediaan sebuah term dalam seluruh dokumen. Semakin sedikit jumlah dokumen yang mengandung term yang dimaksud, maka nilai IDF semakin besar. Rumus IDF adalah :

$$
\operatorname{idf}_{\mathrm{t}}=\log \frac{D}{d f_{t}} \text {.... }
$$

Keterangan :

$\operatorname{idf}_{\mathrm{t}} \quad=$ Inverse Document Frequency

$\mathrm{D} \quad=$ Jumlah Keseluruhan Dokumen

$\mathrm{df}_{\mathrm{t}} \quad=$ Jumlah dokumen yang memuat term $\mathrm{t}$

\subsection{Algoritma Levenshtein Distance}

Levenshtein Distance adalah sebuah algoritma yang menggunakan matriks untuk mengukur angka perbedaan antara 2 string[3]. Jarak antara string diukur berdasarkan angka penambahan karakter (insertion), 
penghapusan karakter (deletion)ataupun penggantian karakter (substitusion) yang diperlukan untuk mengubah string sumber menjadi string target (Ishak dkk., 2012). Berikut rumus matriks dari Levenshtein Distance:

$$
\operatorname{Iev} \mathrm{a}, \mathrm{b}(\mathrm{i}, \mathrm{j})=\left\{\begin{array}{c}
\max (i, j) \text { if } \min (i, j)=0 \\
\min \left\{\begin{array}{c}
\operatorname{lev} a, b(1-j)+1 \\
\operatorname{lev}, a, b(1, j-1)+1 \\
\operatorname{lev} a, b(i-1, j-1)+1(a i \neq b j)
\end{array}\right.
\end{array}\right.
$$

Keterangan:

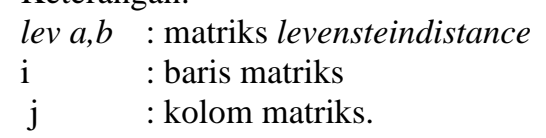

Dalam metode ini memiliki aturan penilaian yang akan dijelaskan dalam contoh sebagai berikut:

1. Jika string sumber (a) adalah "hitung" dan string target (b) juga terisi dengan kata "hitung", maka nilai lev $\mathrm{a}, \mathrm{b}=0$. Sehingga dalam proses tersebut tidak terjadi perubahan apapun dalam dua kata yang diukur jaraknya, karena kedua kata tersebut terhubung sama satu sama lain[6].

2. Jika string sumber (a) adalah "hitung" dan string target (b) adalah "hutang", maka nilai lev a,b =2, karena dalam prosesnya terjadi dua penggantian karakter huruf yaitu dari "i" menjadi " $u$ " dan dari "u" menjadi "a". Proses penggantian tersebut dibutuhkan untuk mengubah string yang asli menjadi string gabungan.

3. Kedua hasil di atas ditemukan melalui perhitungan di dalam matriks dari setiap karakter string yang dibandingkan menggunakan tiga persamaan di dalam nilai minimal.

Selanjutnya setelah didapatkan hasil dari matriks levenshtein di atas, maka dilanjutkan dengan perhitungan seberapa besar nilai kesamaan antara string yang dibandingkan menggunakan rumus berikut:

$$
\text { Similarity }=\left\{1-\frac{\text { edit distance }}{\text { maxLength } h(\text { stra }, \text { strb })}\right\}
$$

Keterangan:

edit distance : hasil dari Levenstein Distance.

maxLength : jumlah string dari kata yang terpanjang antara stra dan strb.

stra : panjang string pertama.

strb : panjang string kedua.

Similarity : nilai kesamaan antara kedua string.

Sehingga dapat ditarik kesimpulan bahwa semakin besar nilai Similarity yang dihasilkan maka semakin besar kesamaan yang dimiliki oleh dua dokumen yang dibandingkan.

\subsection{Pengukuran Performa}

Ketika sebuah sistem telah berhasil dirancang sebagaimana mestinya dan sudah diimplementasikan yang kemudian menghasilkan nilai seperti yang diinginkan, maka tahapan selanjutnya adalah pengukuran performa. Pengukuran performa dilakukan untuk menguji keakuratan, keefektifan dan efisiensi sistem yang dibangun.Terdapat sekumpulan rumus yang dapat digunakan sebagai media pengukuran yang sesuai dengan penelitian yang sedang dilakukan yaitu Precision, Recall dan Accuracy.Precision and Recall adalah matriks perhitungan yang digunkan untuk mengukur kefektifitasan pengambilan informasi.

1. Precision $(\mathrm{P})$ adalah pecahan dari dokumen dan diambil yang relevan.

$$
\text { Precision }=\frac{\#(\text { dokumen hoax terklasifikasi hoax })}{\#(\text { jumlah dokumen terklasifikasi hoax })} \text {. }
$$

2. Recall (R) adalah bagian dari dokumen yang relevan yang diambil.

$$
\text { Recall }=\frac{\#(\text { dokumen hoax terklasifikasi hoax })}{\#(\text { jumlah dokumen hoax yang diuji }} \text {. }
$$

Penjelelasan mengenai Precission dan Recall dijelaskan melalui tabel berikut :

\begin{tabular}{|c|c|c|}
\hline \multicolumn{2}{|c|}{ Tabel II.1 Precission dan Recall } \\
\hline & Relevan & Tidak Relevan \\
\hline Diambil & True Positive (tp) & False Positive (fp) \\
\hline Tidak Diambil & False Negative (fn) & True Negative (tn) \\
\hline
\end{tabular}

Berdasarkan Tabel diatas, dapat dituliskan rumus sebagai berikut untuk menghitung akurasi sebuah sistem menggunakan perhitungan Precision and Recall

$$
\begin{aligned}
& \mathrm{P}=\mathrm{tp} /(\mathrm{tp}+\mathrm{fp}) \\
& \mathrm{R}=\mathrm{tp} /(\mathrm{tp}+\mathrm{fn})
\end{aligned}
$$


Dimisalkan jika terdapat 10 buah dokumen berita yang akan diuji dalam sistem deteksi hoax dan telah diklasifikasi sebelumnya menjadi 5 dokumen memiliki konten hoax dan 5 dokumen merupakan berita orisinil. Kemudian 10 dokumen tersebut diuji dalam sistem dan sistem memberikan hasil bahwa terdapat 7 dokumen yang terdeteksi sebagai konten hoax yaitu 4 berita berkonten hoax dan 3 berita berkonten orisinil. Maka dapat disebutkan bahwa 4 berita berkonten hoax yang diambil merupakan nilai true positive (tp), 3 berita berkonten orisinil yang diambil merupakan nilai false positive (fp), 1 berita berkonten hoax yang tidak diambil merupakan nilai false negative (fn) dan 3 berita berkonten orisinil sisanya yang tidak diambil merupakan nilai true negative (tn).

Selain Precision and Recall, dalam perhitungan performa sistem juga diperlukan adanya perhitungan Akurasi sistem, untuk memastikan seberapa akurat sistem tersebut dapat digunakan dalam mendeteksi konten hoax pada berita.Tingkat akurasi sebuah sistem dapat dihitung menggunakan persamaan berikut :

$$
a c=\frac{\sum m a t c h}{\sum t p} * 100 \%
$$

Keterangan :

$$
\begin{aligned}
& \text { ac } \quad \text { tingkat akurasi }(\%) \\
& \sum m a t c h: \text { jumlahdeteksi yang benar } \\
& \sum t p \quad: \text { jumlah data yang diuji }
\end{aligned}
$$

Jumlah deteksi benar adalah jumlah banyaknya data uji yang telah diuji dan sesuai dengan pengelompokannya, nilai tersebut didapatkan dari penjumlahan antara nilai true positive dan nilai true negative. Kemudian pembaginya adalah total dari seluruh data yang digunakan dalam pengujian

\subsection{PHP (Hypertext Preprocessor)}

PHP atau kependekan dari Hypertext Preprocessor adalah salah satu bahasa pemrograman open source yang sangat cocok atau dikhususkan untuk pengembangan web dan dapat ditanamkan pada sebuah skripsi HTML. Bahasa PHP dapat dikatakan menggambarkan beberapa bahasa pemrograman seperti C, Java, dan Perl serta mudah untuk dipelajari. PHP merupakan bahasa scripting server - side, dimana pemrosesan datanya dilakukan pada sisi server

\section{ANALISA DAN HASIL}

\subsection{Tokenizing}

contoh kasus penulis menggunakan potongan berita hoax yang penulis kutip dari website turnbackhoax.id[7]. Berikut sample berita hoax yang digunakan :

Seorang bayi telah dilahirkan di Israel yang mukanya mirip seperti Dajjal,Allah (s.w.t) telah berkata di dalam Al-Qur'an bahwa seorang bayi yang kelihatan seperti Dajjal akan dilahirkan di Israel dan itu adalah petanda hari perhitungan. Berikut adalah perbandingan sebelum dan sesudah tahap tokenizing adalah sebagai berikut :

\begin{tabular}{|l|l|}
\multicolumn{1}{|c}{ Sebelum Tokenizing } & \multicolumn{1}{c|}{ Tabel III.1 Proses Sebelun } \\
\hline Seorang bayi telah dilahirkan & seorang bayi telah dilahirkan \\
di Israel yang mukanya mirip & di israel yang mukanya mirip \\
seperti Dajjal,Allah (s.w.t) & seperti dajjal allah \\
telah berkata di dalam Al- & swt telah berkata di \\
Qur'an bahwa seorang bayi & dalam alquran bahwa \\
yang kelihatan seperti Dajjal & seorang bayi yang kelihatan \\
akan dilahirkan di Israel dan & seperti \\
itu adalah petanda hari & dajjal akan dilahirkan di israel \\
perhitungan. & dan itu adalah pertanda hari \\
& perhitungan \\
\hline
\end{tabular}

3.2. Stopword Removal atau Filtering

Tabel III.2 Proses Sebelum dan Sesudah Stop Removal/Filtering Teks

\begin{tabular}{|l|l|}
\hline \multicolumn{1}{|c|}{ Sebelum Filtering } & \multicolumn{1}{c|}{ Sesudah Filtering } \\
\hline seorang bayi telah dilahirkan & seorang bayi -dilahirkan israel \\
israel yang mukanya mirip & - \\
seperti dajjal & mukanya mirip -dajjal allah \\
allah swt telah berkata di & swt \\
dalam & berkata - - alquran \\
alquran bahwa seorang bayi & seorang bayi \\
yang kelihatan seperti dajjal & - kelihatan - dajjal- \\
akan dilahirkan di israel & dilahirkan -israel --- \\
dan itu adalah petanda hari & petanda hari perhitungan. \\
perhitungan. & \\
& \\
\hline
\end{tabular}

\subsection{Stemming Nazief \& Andriani}

Perancangan Sistem Pendeteksi Berita Hoax Menggunakan Algoritma Levenshtein Distance Berbasis Php (Nurhayati dan Aprilianda Pasaribu) 
Tabel III.3 Proses Sebelum dan Sesudah Stemming

\begin{tabular}{|l|l|}
\hline Sebelum Stemming & \multicolumn{1}{|c|}{ Sesudah Stemming } \\
\hline bayi & bayi \\
dilahirkan & lahir \\
israel & israel \\
mukanya & muka \\
mirip & mirip \\
dajjal & dajjal \\
allah & allah \\
swt & swt \\
berkata & kata \\
alquran & alquran \\
seorang & orang \\
bayi & bayi \\
kelihatan & lihat \\
dajjal & dajjal \\
dilahirkan & lahir \\
israel & israel \\
petanda & tanda \\
hari & hari \\
perhitungan & hitung \\
& \\
\hline
\end{tabular}

3.4. Sorting

Sorting teks digunakan untuk mengurutkan kata hasil dari stemming secara ascending atau menaik, sehingga pencocokan string dokumen dilakukan pada sata yang sudah terurut.

\begin{tabular}{|c|c|}
\hline Sebelum Sorting & Sesudah Sorting \\
\hline $\begin{array}{l}\text { orang } \\
\text { bayi } \\
\text { lahir } \\
\text { israel } \\
\text { muka } \\
\text { mirip } \\
\text { dajjal } \\
\text { allah } \\
\text { swt } \\
\text { kata } \\
\text { alquran } \\
\text { orang } \\
\text { bayi } \\
\text { lihat } \\
\text { dajjal } \\
\text { lahir } \\
\text { israel } \\
\text { tanda } \\
\text { hari } \\
\text { hitung }\end{array}$ & $\begin{array}{l}\text { Allah } \\
\text { alquran } \\
\text { bayi } \\
\text { bayi } \\
\text { dajjal } \\
\text { dajjal } \\
\text { hari } \\
\text { hitung } \\
\text { israel } \\
\text { israel } \\
\text { kata } \\
\text { lahir } \\
\text { lahir } \\
\text { lihat } \\
\text { mirip } \\
\text { muka } \\
\text { orang } \\
\text { orang } \\
\text { swt } \\
\text { tanda }\end{array}$ \\
\hline
\end{tabular}

\subsection{Pembobotan Kata Algoritma TF-IDF}

Setelah tahap teks preprocessing selesai,tahap selanjutnya adalah pembobotan kata (term). Dalam pembobotan kata (term) ini,setiap kata yang telah melewati proses preprocessing, akan di-parsing (diuraikan) terlebih dahuludan disimpan dalam database, kemudian dihitung jumlah kemunculan setiap katanya. Setelah berita yang diinput dilakukan prepoessing dan menjadi data kata hoax, langkah selanjutnya adalah dengan membandingkan data tesebut dengan data latih. Kemudian dilakukan perhitungan untukmengetahui bobot perkata dengan menghitungjumlah term frequency dokumen (tf) terlebihdahulu, kemudian menghitung nilai jumlahdokumen yang memiliki term (df), danselanjutnya menghitung nilai idf. Setelah nilai TF dan IDF sudah didapat, maka langkah terakhiradalah menentukan bobot kata denganmengalikan TF dan IDF. Hasil dari prosesperhitungan ini disimpan dalam database danakan dilanjutkan dengan tahap berikutnyauntuk dilakukan perhitungan menggunakan algoritma Levenshten Distance yang merupakan tahap akhir proses.

\section{Tabel III. 5 Koleksi Dokumen Hoax}

\begin{tabular}{|c|l|}
\hline & $\begin{array}{l}\text { Badan Meteorologi dan Geofisia menyatakan } \\
\text { bahwa akan terjadi kemarau panjang yang } \\
\text { akan melanda dunia. Diperkirakan kemarau }\end{array}$ \\
Dokumen 1 & $\begin{array}{l}\text { panjang tersebut akan dimulai tahun 2019 } \\
\text { hingga 2022. Cadangan air dunia saat ini }\end{array}$ \\
& $\begin{array}{l}\text { hanya tersisa 3\% saja. Lalu apa artinya } \\
\text { informasi ini bagi kita?Artinya adalah }\end{array}$ \\
\hline
\end{tabular}

Jurnal SAINTIKOM Vol. 19, No. 2, Agustus 2020 : 74-84 


\begin{tabular}{|c|c|}
\hline & $\begin{array}{l}\text { kemunculan Dajjal telah sangat dekat. Dan } \\
\text { munculnya Imam Mahdi telah berada di } \\
\text { tengah-tengah kita tanpa kita sadari. Ini } \\
\text { berarti apa yang disabdakan Rasulullah telah } \\
\text { terbukti. }\end{array}$ \\
\hline $\begin{array}{c}\text { Dokumen } 2 \\
\text { (d2) }\end{array}$ & $\begin{array}{l}\text { Seorang pria di Bojonegoro meninggal akibat } \\
\text { menggunakan Hp.Dia mendengar musik } \\
\text { pakai Handset, saat Hpnya di Charge dan } \\
\text { ketiduran.Arus Listrik masuk melalui telinga } \\
\text { sampai ke sekujur tubuhnya. Kulitnya } \\
\text { meletup letup sampai membentuk lubang2 di } \\
\text { seluruh tubuh nya...Sekali lagii, jangan } \\
\text { pernah gunakan Hp saat sedang di charge } \\
\text { sepenting apapun keadaannya karena ini bisa } \\
\text { mengancam keselamatan. }\end{array}$ \\
\hline \multirow[t]{2}{*}{$\begin{array}{c}\text { Dokumen } 3 \\
\text { (d3) }\end{array}$} & $\begin{array}{l}\text { Anak perempuan mertua saya (umur } 31 \text { thn) } \\
\text { baru meninggal semalam disebabkan oleh } \\
\text { leukimia. Almarhum semasa hidupnya } \\
\text { meneliti utk gelar Master in botanical di } \\
\text { kampus USM mengkaji sejenis tumbuhan ini. } \\
\text { Rekan satu tim research beliau sdh meninggal } \\
\text { setahun yg lalu mengidap penyakit leukimia } \\
\text { juga. Almarhum dpt bertahan hingga } \\
\text { semalam. Memang hsl penelitiannya telah } \\
\text { disahkan oleh pihak kampus USM dan pihak } \\
\text { Kementrian Kesehatan bhw leukimia itu dpt } \\
\text { ditimbulkan dari tumbuhan tsb. Jadi cerita D } \\
\text { Hizzad Bole penyebab kanker darah } \\
\text { (leukimia) ternyata terbukti. Di Cina sdh } \\
\text { cukup lama diketahui tentang bahaya tanaman } \\
\text { ini, tapi hanya diberitakan suratkabar Cina } \\
\text { saja. Sedangkan ditempat kita tanaman ini } \\
\text { dirawat \& dijadikan tanaman hias di rumah.. }\end{array}$ \\
\hline & $\begin{array}{l}\text { PERHATIAN \& WASPADA.Jika ada } \\
\text { tanaman ini dirumah, silahkan secepatnya } \\
\text { musnah dengan membakarnya sebelum } \\
\text { tanaman berbunga. Karena dari bunganya } \\
\text { menyebabkan kanker darah (leukimia) }\end{array}$ \\
\hline \multirow{3}{*}{$\begin{array}{c}\text { Dokumen } 4 \\
\text { (d4) }\end{array}$} & $\begin{array}{l}\text { Teman2 yb, sekedar menginformasikan saja, } \\
\text { karena fenomena Equinox yang akan } \\
\text { mempengaruhi Malaysia, Singapura dan } \\
\text { Indonesia di } 5 \text { hr ke depan. Disarankan utk } \\
\text { tinggal di dalam rumah atau diruang kerja } \\
\text { terutama dari jam 12:00-15:00 setiap hari. } \\
\text { Suhu akan berfluktuasi sampai } 40 \text { derajat } \\
\text { Celcius. Hal ini dapat dengan mudah } \\
\text { menyebabkan dehidrasi dan matahari stroke. ( } \\
\text { Fenomena ini adalah karena matahari } \\
\text { diposisikan tepat di atas garis khatulistiwa pd } \\
\text { tgl } 20 \text { Maret. }\end{array}$ \\
\hline & $\begin{array}{l}\text { Harap menjaga kesehatan diri agar tdk } \\
\text { dehidrasi. Setiap orang setidaknya } \\
\text { mengkonsumsi sekitar } 3 \text { liter cairan setiap } \\
\text { hari. Memonitor tekanan darah. } \\
\text { Kemungkinan mendapatkan serangan } \\
\text { panas.Mandi air dingin sesering mungkin. } \\
\text { Mengurangi daging, perbanyak buah2an \& } \\
\text { sayuran. }\end{array}$ \\
\hline & $\begin{array}{l}\text { Tempatkan lilin tidak terpakai di luar rumah. } \\
\text { Jika lilin bisa meleleh, berarti udara dalam } \\
\text { tingkat yang cukup berbahaya.Jika bisa selalu } \\
\text { menempatkan ember dgn air setengah penuh }\end{array}$ \\
\hline
\end{tabular}

Perancangan Sistem Pendeteksi Berita Hoax Menggunakan Algoritma Levenshtein Distance Berbasis Php (Nurhayati dan Aprilianda Pasaribu) 


\begin{tabular}{|c|c|}
\hline & $\begin{array}{l}\text { di ruangan, ruang tamu \& di setiap kamar } \\
\text { untuk menjaga suhu tetap lembab. } \\
\text { Pengalaman pertama di Malaysia dan } \\
\text { Singapura. Heat stroke yang tidak memiliki } \\
\text { gejala indikasi. Setelah pingsan, yang serius } \\
\text { berbahaya seperti kegagalan organ } \\
\text { dalam.Hari menjadi lebih hangat mungkin } \\
\text { lebih dari } 2 \text { minggu ke depan. Bisa sampai } 9 \\
\text { derajat lebih tinggi dari biasanya ! Terima } \\
\text { kasih. }\end{array}$ \\
\hline $\begin{array}{c}\text { Dokumen } 5 \\
\text { (d5) }\end{array}$ & $\begin{array}{l}\text { Susanti, warga Sulawesi Selatan didenda } \\
\text { 700rb karena telah melahirkan di rumah. Ia } \\
\text { yang tidak memiliki uang lebih memilih } \\
\text { melahirkan dirumah dengan jasa dukun } \\
\text { beranak. Namun pihak puskesmas setempat } \\
\text { mengatakan bahwa setiap kelahiran harus } \\
\text { dilakukan di puskesmas, dimana uangnya } \\
\text { untuk menggaji para staf. Peraturan aneh ini } \\
\text { pun memaksa Susanti meminjam uang ke } \\
\text { tetangga untuk membayar denda. }\end{array}$ \\
\hline
\end{tabular}

Dokumen data latih diatas dilakukan proses Text Preprocessing. Sehingga menjadi : Tabel III.6 Hasil PreprocessingData Latih

\begin{tabular}{|l|l|l|l|l|}
\hline \multicolumn{1}{|c|}{ d1 } & \multicolumn{1}{c|}{ d3 } & d4 & d5 \\
\hline ada & akibat & almarhum & ada & anak \\
air & ancam & anak & air & aneh \\
arti & apa & bahaya & air & atur \\
badan & arus & bakar & alami & bahwa \\
bagi & bisa & baru & atas & bayar \\
bukti & bojonegoro & beliau & bahaya & denda \\
cadang & charge & belum & banyak & denda \\
dajjal & charge & berita & bisa & dukun \\
dekat & dengar & bole & buah & gaji \\
dunia & guna & botanical & cair & harus \\
geofisika & guna & kampus & celcius & jasa \\
hingga & handset & bukti & cukup & kata \\
imam & hp & cepat & hari & lahir \\
informasi & hp & cerita & dapat & lahir \\
jadi & jangan & cina & darah & lahir \\
kemarau & keadaan & darah & mungk & lebih \\
kira & bujur & gelar & in & milik \\
landa & kulit & hias & dehidr & paksa \\
mahdi & lalu & hidup & asi & pihak \\
meteorologi & letup & hingga & & puskes \\
mulai & listrik & hizzad & & mas \\
muncul & lubang & hsl & & pilih \\
nyata & masuk & idap & & \\
panjang & musik & jadi & & \\
rasulullah & orang & jenis & & \\
saat & pakai & kabar & & \\
sabda & penting & kaji & & \\
& & & \\
\hline
\end{tabular}

Setelah dilakukan pra-pemrosesan tekspada masing-masing dokumen dalam koleksi, maka selanjutnya dilakukan perhitungan term weightening TF-IDF, sebagai berikut :

Tabel III.7 Hasil Perhitungan TF-IDF 


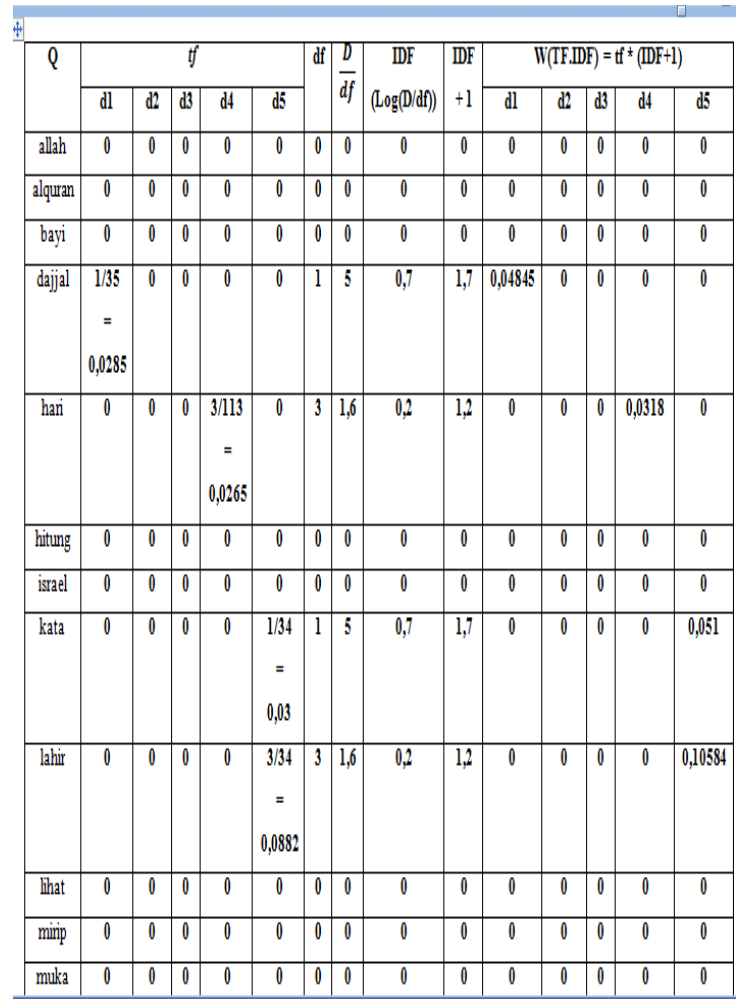

\section{Jumlah string d1 $=35, \mathrm{~d} 2=34, \mathrm{d3}=70, \mathrm{d4}=113, \mathrm{d5}=34$}

Jika kata hoaxterdapat dalam list berita maka nilai hitung akan lebih besar dari 0 , sehingga proses menambahkan 1 pada perhitungan dokumen.

\subsection{Perhitungan Levenshtein Distance}

untuk menghitung jarak antara 2 kata (string) yang dibandingkan dan juga untuk mengukur kesamaan antara 2 kata yaitu kata sumber (a) dan kata target (b). Kata sumber merupakan input berita yang dimasukkan user (data uji), sedangkan kata target merupakan database kata hoks (data latih). penyeleksian panjang kedua string terlebih dahulu. Jika salah satu atau kedua string merupakan string kosong, jalannya algoritma ini berhenti dan memberikan hasil edit distance bernilai 0 (nol). Apabila string yang dibandingkan panjangnya tidak bernilai 0, maka dilakukan perhitungan. Misal string a adalah "LAHIR" dan string b adalah "ORANG", Jika dilihat secara sekilas, kedua string tersebut memiliki jarak 5. Berarti untuk mengubah string "LAHIR" menjadi "ORANG" diperlukan 5 operasi, yaitu : Dengan menggunakan representasi matriks dapat dilihat pada tabel dibawah.

Tabel III.8 Matriks Perhitungan Levenshtein Distance

\begin{tabular}{|l|l|l|l|l|}
\hline L & A & H & I & R \\
\hline O & R & A & N & G \\
\hline
\end{tabular}

Berdasarkan tabel diatas kita telah melakukan perbandingan antara string a "LAHIR' yang memilki panjang 5 dengan string b "ORANG" memilki panjang 5. Dari hasil perbandingan maka didapatilah nilai jarak perbedaan antara 2 string diatas adalah 5 yang diambil dari nilai matriks pada ujung kanan bawah matriks. Jika panjang string keduanya tidak nol, berarti setiap sekuen memilki sebuah karakter. Sehingga perhitungan yang dilakukan dengan mentransformasikan string a (kata sumber) menjadi b (kata target). Jika string a sama

\begin{tabular}{|c|c|c|c|c|c|c|}
\hline & & L & A & H & I & R \\
\hline & $\mathbf{0}$ & $\mathbf{1}$ & $\mathbf{2}$ & $\mathbf{3}$ & $\mathbf{4}$ & $\mathbf{5}$ \\
\hline $\mathbf{O}$ & $\mathbf{1}$ & 1 & 2 & 3 & 4 & 5 \\
\hline $\mathbf{R}$ & $\mathbf{2}$ & 2 & 2 & 3 & 4 & 5 \\
\hline $\mathbf{A}$ & $\mathbf{3}$ & 3 & 3 & 3 & 4 & 5 \\
\hline $\mathbf{N}$ & $\mathbf{4}$ & 4 & 4 & 4 & 4 & 5 \\
\hline $\mathbf{G}$ & $\mathbf{5}$ & 5 & 5 & 5 & 5 & $\mathbf{5}$ \\
\hline
\end{tabular}
dengan string b, maka nilai cost sama dengan 0. Misalnya pada String a (i1) diawali karakter "D" dan karakter String b (j1) diawali dengan karakter "D", cost sama dengan 0 karena tidak ada perubahan apapun yang dilakukan oleh sistem. Jika string a berbeda dengan string b, maka nilai cost-nya 1 karena membutuhkan 1x operasi perubahan dari string a menjadi string a. Sehingga, nilai edit distance-nya dari pentransformasian sekuen pertama menjadi sekuen kedua ditambah 1. Pada matriks diatas, saat string b karakter "O" dan string a karakter "L" nilai cost sama dengan 1, karena membutuhkan 1 operasi yaitu Subtitusi atau merubah L menjadi O.Pada

Perancangan Sistem Pendeteksi Berita Hoax Menggunakan Algoritma Levenshtein Distance Berbasis Php (Nurhayati dan Aprilianda Pasaribu) 
perbandingan karakter selanjutnya, nilai cost pertama mempengaruhi nilai cost selanjutnya. Nilai cost terkecil merupakan nilai cost yang digunakan.

\subsection{Perhitungan Nilai Similiarity}

Setelah mendapatkan nilai edit-distance, langkah selanjutnya adalah menghitung nilai similiarity. Jika nilai similarity adalah 1, maka kedua string yang dibandingkan sama. Di lain hal, jika similarity 0, maka kedua string yang dibandingkan tidak sama.

$$
\begin{aligned}
& \text { Similarity }=\left\{1-\frac{\text { edit distance }}{\text { maxLength }(\text { stra,strb })}\right\} \\
& \text { Similarity }=\left\{1-\frac{5}{\text { maxLength }(5,5)}\right\} \\
& \text { Similarity }=\left\{1-\frac{5}{5}\right\} \\
& \text { Similarity }=\{1-1\} \\
& \text { Similarity }=0
\end{aligned}
$$

Nilai kesamaan (similarity) kata tersebut dikalikan dengan nilai bobot (TF-IDF) dari kata target yang dibandingkan yaitu 'ORANG' dengan bobot kata 0,042 dan 0,01232. Perhitungan sebagai berikut :

Tfidfmix $=$ Similarity $* \mathrm{bt}$

Tfidfmix $=0 * 0,042=0$

Tfidfmix $=0 * 0,01232=0$

Selanjutnya perkalian similiarity dan TF-IDF akan dijumlahkan dengan hasil perkalian yang sama namun dengan nilai similiaritydan TF-IDF yang berbeda. Kemudian kata target akan disimpan di data target. Hal ini bertujuan untuk menghitung banyaknya kata target yang memiliki nilai jarak minimal yang sama terhadap satu kata sumber. Perhitungan selanjutnya adalah menghitung rata-rata dari keseluruhan hasil perkalian similiarity dan TF-IDF dan didapatilah nilai dalam $\%$.

\section{IMPLEMENTASI}

Setelah sistem sudah terbentuk, maka selanjutnya dilakukan pengujian pada sistem. Teks berita yang sudah diuji akan menghasilkan nilai, jika nilai yang dihasilkan besar maka semakin besar kemungkinan teks berita tersebut mengandung unsur hoax dan sebaliknya. Ketika proses pengujian selesai, selanjutnya adalah masuk ke tahap analisis sistem. Sebelum itu, seluruh nilai yang dihsailkan oleh proses pengujian akan diubah dalam bentuk tabel untuk mengetahui batas-batas yang dapat digunakan sebagai penentu klasifikasi hoax sebuah berita. Dalam tahap analisis, sistem akan dinilai menggunakan pengukuran keakuratan sistem menggunakan Precision and Recall dan Pengukuran Akurasi. Dalam sistem akan dilihat ketepatan dan akurasinya melalui perhitungan tersebut. maka rumus dapat lebih diperjelas dengan memasukkan unsur perhitungan berdasarkan data-data yang dihasilkan dalam pengujian.Berikut penjelasan lebih lanjut jika dalam rumus dimasukkan unsur yang perlu dihitung berdasarkan data pengujian.

1. Precision (P)mengukur ketepatan sistem melakukan klasifikasi jenis dokumen hoax atau non-hoax.

$$
\text { Precision }=\frac{\#(\text { dokumen hoax terklasifikasi hoax })}{\#(\text { jumlah dokumen terklasifikasi hoax })}
$$

2. Recall (R) adalah mengukur ketepatan menghasilkan nilai-nilai yang relevan sehingga dokumen dapat terklasifikasi.

$$
\text { Recall }=\frac{\#(\text { dokumen hoax terklasifikasi hoax })}{\#(\text { jumlah dokumen hoax yang diuji }}
$$

Gagasan tersebut dapat diperjelas melalui tabel berikut.

Tabel III.9 Precission dan Recall Berdasarkan Data Pengujian

\begin{tabular}{|l|l|l|}
\hline & & \\
Prediksi & Dokumen Hoax & DokumenNon-Hoax \\
\hline Terklasifikasi Hoax & & False positive $(\mathrm{fp})$ \\
\hline Terklasifikasi Non-Hoax & True positive $(\mathrm{tp})$ & True negative $(\mathrm{tn})$ \\
\hline \multicolumn{2}{|c|}{ Palse negative $(\mathrm{fn})$} \\
Precision $=\mathrm{tp} /(\mathrm{tp}+\mathrm{fp})$ \\
Recall $=\mathrm{tp} /(\mathrm{tp}+\mathrm{fn})$
\end{tabular}


Kemudian berikut adalah rumus akurasinya :

$$
a c=\frac{\sum m a t c h(t p+t n)}{\sum t p} \times 100 \%
$$

Gambar IV.1 Form Home User

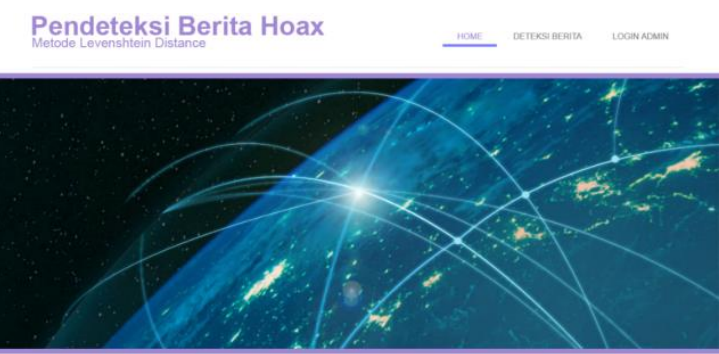

Pendeteksi Berita Hoax

Gambar IV.8Form Input Berita

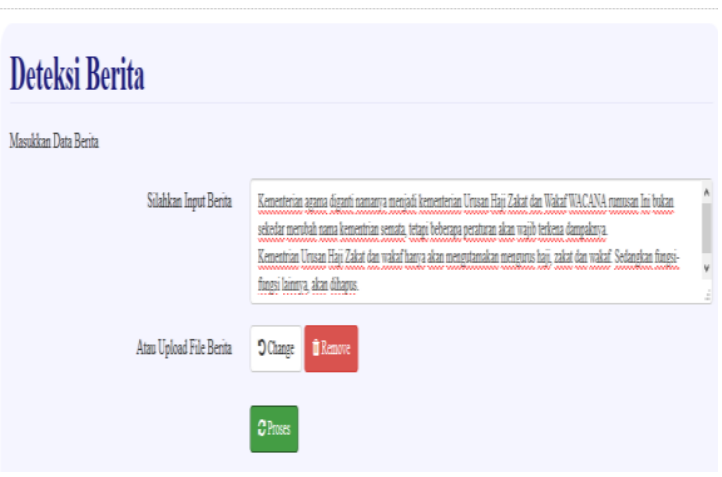

\section{KESIMPULAN}

Terdapat langkah-langka untuk menerapkan algoritma Levenshtein Distance dalam sistem pendeteksi berita hoax, yaitu :

a. Pembuatan Dokumen Data Target yang di dalamnya terdapat kumpulan kata hoax yang sudah disederhanakan dalam Prapemrosesan Kata (Prepocessing Text) dan Penyeleksian kata dengan memberi bobotpada setiap kata menggunakan TF-IDF.

b. Pembuatan Sistem Deteksi Hoax yang di dalamnya terdapat beberapa proses hingga menghasilkan nilai klasifikasi yaitu Prapemrosesankata sumber, membandingkan kata sumber dan katatarget, menghitung jarak (Levenshtein Distance), memberi bobot(TF-IDF), dan menghitung hasil akhir sekaligus pengklasifikasian.

Sistem yang dibangun dapat melakukan penerapan algoritma TF-IDF dan algoritma levenshtein distance yang mendeteksi berita hoaks dan menghasilkan nilai keakurasian hasil deteksi berita.

Kuantitas data latih, keakuratan data kata dasar, dan stopword mempengaruhi keakuratan hasil deteksi berita. Penggunaan proses stemming akan lebih mampu mendeteksi berita jika dalam database memiliki kata dasar yang umum terdapat dalam berita hoaks sehingga tidak menghasilkan kerancuan dalam kata dasar yang dihasilkan. Batas 0,1dengan data uji 40 dokumen denganpembagian 20 berita non-hoax dan 20 berita hoax, memiliki nilaiPrecision, Recall dan Accuracy yang konsisten yaitu Precision 0,7;Recall 0,7 dan Accuracy $70 \%$.Yang berarti semakin banyak kata hoaxyang dijadikan data latih, maka semakin akurat sistem melakukanpendeteksian

\section{REFERENSI}

[1] [1] Vuković, M., Pripužić, K., \& Belani, H. (2009). An intelligent automatic hoax detection system. Lecture Notes in Computer Science (Including Subseries Lecture Notes in Artificial Intelligence and Perancangan Sistem Pendeteksi Berita Hoax Menggunakan Algoritma Levenshtein Distance Berbasis Php (Nurhayati dan Aprilianda Pasaribu) 
Lecture Notes in Bioinformatics), 5711 LNAI(PART 1), 318-325. https://doi.org/10.1007/978-3-64204595-0_39

[2] [2] Silverman, Craig. ,Lies, Damn Lies and Viral Content. Columbia Journalism Review, 2015, 1149. https://doi.org/10.7916/D8Q81RHH.

[3] [3] Weddiningrum, Frista Gifti. Deteksi Konten Hoax Berbahasa Indonesia Pada Media Social Menggunakan Metode Levenshtein Distance, Skripsi, Surabaya [ID] : Universitas Negeri Sunan Ampel Surabaya.

[4] [4] Ryansyah Adi dan Sri Andayani. Implementasi Algoritma TF-IDF pada Pengukuran Kesamaan Dokumen, Jurnal Sistem dan Teknologi Informasi Komunikasi 1(1) : 2, diakses tanggal 18 Juli 2019.

[5] [5] Rahadi Dedi, Rianto. 2017. Perilaku Pengguna Dan Informasi Hoax Di Media Sosial, Jurnal Manajemen dan Kewirausahaan 5(1)

61:62,jurnal.unmer.ac.id/index.php/jmdk/article/download/1342/933,diakses tangggal 24 Mei 2019.

[6] [6] Nangili, Supandi, dkk. 2014. Pengujian Algoritma Levenshtein Distance dan Algoritma Term Frequency Inverse Document Frequency (TF-IDF) untuk penilaian jawaban essay, Karya Ilmiah, Gorontalo [ID] : Universitas Gorontalo.

[7] [7] Omar, Braddley Muhammad,dkk. Pengoreksian Ejaan Kata Berbahasa Indonesia Menggunakan Algoritma Levenshtein Distance, Prosiding Annual Research Seminar 2017 3(1): 169 :170, diakses tanggal 15 Agustus 2019. 